\title{
Selective screening: isolation of fungal strains from contaminated soils in Austria
}

\section{Selektives Screening: Isolierung von Pilzstämmen aus schadstoffbelasteten Böden in Österreich}

\author{
Caroline Poyntner ${ }^{1 *}$, Max Prem $^{1}$, Oliver Mann², Barbara Blasi ${ }^{1}$, Katja Sterflinger ${ }^{1}$ \\ ${ }^{1}$ VIBT EQ Extremophile Center, Department of Biotechnology, University of Natural Resources and Life Sciences (BOKU), Muthgasse 18, \\ 1190 Vienna, Austria \\ ${ }^{2}$ Department of Organic Chemistry, ESW Consulting Wruss ZT GmbH, Rosasgasse 25-27, 1120 Vienna, Austria \\ * Corresponding author: caroline.poyntner@boku.ac.at
}

Received: 14 September 2017, received in revised form: 6 December 2017, accepted: 7 December 2017

\begin{abstract}
Summary
Microorganisms are potent contributors to maintaining a safe environment as they are able to degrade organic toxicants. For environmental applications, mostly bacteria are used while fungal strains have received less attention. However, they are able to degrade highly persistent organic contaminants and survive extreme conditions, and may thus be promising organisms. To find new fungal candidates for these applications, twelve soil samples from polycyclic aromatic hydrocarbon (PAH) contaminated sites in Austria were used to isolate fungal strains. A microplate screening method using PAH contaminated soil as inoculant was set up to isolate fungal strains being able to live in presence of toluene, hexadecane, or polychlorinated biphenyl 126. Not many microbial strains are known that degrade these three contaminants, while the PAH contamination acted as selective pressure for the soil microbiota. After obtaining pure cultures, the fungal strains were further screened for their ability to live in the presence of one of the three contaminant substrates. The potential for technical application of the 11 best performing strains, identified using ITS and 18S rDNA, is discussed. The presented microtiter plate screening method is a cost efficient and quick approach to identify fungal strains for pollutant degradation and results in candidates with a high relevance for bioremediation techniques.
\end{abstract}

Keywords: biodegradation, bioremediation, fungi, screening, contaminated soil

\section{Zusammenfassung}

Mikroorganismen leisten durch ihrer Fähigkeit organische Schadstoffe abzubauen einen wichtigen Beitrag zur Erhaltung einer saubere Umwelt. Für Anwendungen in der Umwelt finden meist Bakterienstämme ihre Anwendung, während viele Pilzstämme auch die nötigen Eigenschaften besitzen, persistente, organische Schadstoffe abzubauen. Sie haben zusätzlich den Vorteil, extreme Bedingungen zu überleben. Pilze eignen sich als vielversprechende Kandidaten für biologische Sanierungen. Um mögliche Kandidaten zu finden, wurden in unserer Studie zwölf mit polyaromatischen Kohlenwasserstoffen (PAKs) kontaminierte Bodenproben von verschiedenen Standorten in Österreich als Inokulum zur Isolierung von Pilzstämmen genutzt. Hierfür wurde ein selektives Mikrotiterplatten Screening in Gegenwart von Toluol, Hexadekan oder polychloriertes Biphenyl (PCB) 126 entwickelt. Die drei Schadstoffe wurden gewählt, da nicht viele Mikroorganismen diese abbauen können, während die PAKs als selektiver Druck für die Bodenmikroorganismen wirkte. Von den resultierenden Pilzkulturen wurden Reinkulturen erstellt und anschließend ein weiteres Mal auf ihr Wachstum mit den drei Schadstoffen als Kohlenstoffquelle getestet. Das technische Anwendungspotential der elf Stämme mit dem besten Wachstum, die mit Hilfe von ITS und 18S rDNA Sequenzierung identifiziert wurden, wird diskutiert. Die präsentierte Screening Methode ist eine effiziente und schnelle Methode, um abbauende Pilzstämme mit einem hohen Anwendungspotenzial zu identifizieren. Durch die Isolierung aus österreichischem Boden eignen sich die isolierten Pilze besonders für eine Anwendung im Schadstoffabbau im zentraleuropäischen Raum.

Schlagworte: biologischer Abbau, biologische Sanierung, Pilze, Screening, kontaminierte Böden 


\section{Introduction}

Environmental pollution with man-made contaminants poses potential risks for humans, animals and plants due to their persistence and toxicity. Contaminants are very different in their chemical structure, show different abundance and stability in the environment and differ in the accessibility for microorganisms. In addition, they can strongly adsorb to soil particles and remain immobilized (Boonchan et al., 2000; Pinto and Moore, 2000). Contaminants have a large extent: from crude oil ingredients as benzene, toluene, ethylbenzene and xylene (BTEX), to polycyclic aromatic hydrocarbons (PAHs) from coal and tar residues, hexadecane from diesel to chemical liquid waste as polychlorinated biphenyls (PCB). The removal of these toxic compounds is a challenge and can be very cost intensive. New technologies and cleanup methods together with a better understanding of used methods, to improve degradation time and rate, are needed.

Biofilter systems are a common gas or wastewater treatment technologies that use biological mechanisms to degrade contaminants. They are cost-effective compared to physicochemical processes, especially in case of high gas flow rates with low concentrations of volatile organic compounds (Maestre et al., 2007). Mostly bacteria are used in these systems, but fungal strains can also be good candidates. Fungi have the advantage of being able to withstand harsh conditions like low water availability, varying $\mathrm{pH}$ values or changes in temperature and are able to degrade great variety of contaminants (Cox, 1995). Additionally, bacterial gas biofilters have poor degrading abilities concerning hydrophobic contaminants, as they are poorly absorbed due to their low water solubility (van Groenestijn et al., 2001). One technical option to overcome this problem is fungal strains grown on inert packaging material (van Groenestijn et al., 2001). Examples of successful usage are Exophiala jeanselmei, used to treat styrene polluted air (Cox, 1995), and Aspergillus niger, used for degradation of hexane (Spigno et al., 2003; Groenestijn and Kraakman, 2005).

Another option to use fungal strains is residual contaminations in soils, which often remain untreated after the excavation of highly contaminated hot spots due to the high costs. In these situations, in situ bioaugmentation may be a good alternative. Although it requires longer time compared to traditional approaches, the bioremediation approach may be preferable due to its lower cost and environmental impact (Harms et al., 2011). Bioaugmentation might be a promising approach depending on the microbi- ota and their survival rate in the soil (Mrozik et al., 2010). Therefore, strains from contaminated soil might be a solution, as they are already adapted to the contaminant rich environment. Bacteria and fungi are ubiquitously present in sediments and play a significant role in natural biodegradation (Atlas, 1995). Fungal strains have extensive metabolic capabilities eligible for decontamination, but their potential use in bioremediation to date has only received limited attention (Harms et al., 2011). Due to the fungal ability to grow in a hyphal form, they can reach and penetrate contaminated soil easily (April et al., 1999). There are limitations in fungal application, which have to be kept in mind, for example, fungal degradation can be a slower process, the strains might need longer time to adapt and sometimes degradation leads to intermediates that were not completely removed by the strain (Sasec and Cajthaml, 2014; Kulshreshtha et al., 2014; Zahid Maqbool et al., 2016). Interaction with bacteria in degradation processes has not been studied extensively, but might be very important for the improvement of remediation performance.

The group of white-rot basidiomycete fungi and their molecular degradation tools, that is, extracellular ligninolytic enzymes and accessory enzyme, are normally used for lignin degradation and has been found to be useful for contaminant degradation. However, white-rot fungi typically grow in compact wood and favor acidic condition (Marco-Urrea et al., 2015). Therefore, known non-ligninolytic fungal strains with the possibility to live on contaminants are often better candidates for bioaugmentation, as they are able to live in extreme conditions such as high or changing $\mathrm{pH}$ or desiccation.

To identify key players of fungal degradation in contaminated soil, for the first time we set up a microtiter plate screening method based on the screening method described by Blasi et al. (2016) and developed a quick and high throughput screening method using the contaminated soil as inoculant. Twelve soil samples were used to obtain a broad range of fungal strains and investigate differences between the sites and varying PAH contamination that acted as selective pressure for the microbiota. We were able to isolate 93 different fungal strains from the first screening where contaminated soil was used as inoculant and growth in the presence of toluene, PCB 126 and hexadecane was tested. These contaminants were chosen as they offer a broad range of different chemical structures and not many microbes are known to be able to degrade PCB. Pure fungal strains were cultivated and growth in the presence of the three contaminants was confirmed re- 
peating the microtiter plate screening method. The best growing 11 strains were identified by ITS and partial $18 \mathrm{~S}$ rDNA sequencing data. These strains are discussed for their potential application in the field.

\section{Materials and Methods}

\subsection{PAH Analysis of contaminated soil samples}

Soil samples from different contaminated sites were provided by ESW Consulting Wruss ZT GmbH. The samples were dried with $\mathrm{Na}_{2} \mathrm{SO}_{4}$ (Merck Millipore) and $30 \mathrm{~g}$ of homogenized soil sample was extracted on a Soxhlet apparatus for at least 6 hours using $150 \mathrm{~mL}$ of cyclohexane (LGC standards $\mathrm{GmbH}$ ) as a solvent, containing six deuterated internal standards (naphthalene D8, acenaphthene D10, phenanthrene D10, fluoranthene D10, benzo[a] anthracene D12, and benzo[a] pyrene D12, Dr. Ehrenstorfer GmbH). After extraction, the solution was brought to $150 \mathrm{~mL}$ (to compensate for possible solvent loss during extraction). $300 \mu \mathrm{l}$ of this extract was transferred into a cyclohexane preconditioned clean up column filled with aluminum oxide (Merck production chemicals, $1.5 \mathrm{~mL}$ ) and $\mathrm{Na}_{2} \mathrm{SO}_{4}$ and then flushed twice with $600 \mu \mathrm{l}$ of cyclohexane. The resulting extracts were then analyzed by large volume gas chromatography - mass spectrometry (Agilent 7890A coupled to a 5975C inert XL mass spectrometer) using a ZB-5MSi fused silica capillary column (5\%-diphenyl- 95\%-dimethyl polysiloxane, $30 \mathrm{~m} \times 0.25 \mathrm{~mm} \mathrm{ID} \times 0.25 \mu \mathrm{m}$ ) from Phenomenex.

\subsection{Microtiter plate screening method for pollutant degrading fungal strains}

\subsubsection{Screening method for pollutant degrading fungi using PAH contaminated soils as inoculants, iso- lation and cultivation of pure cultures}

Unsieved soil of each sample (approximately $0.15 \mathrm{~g}$ ) was dissolved in $1 \mathrm{~mL}$ of $0.9 \%$ sterile $\mathrm{NaCl}$ solution and vortexed to gain a homogenized liquid inoculant. $20 \mu \mathrm{l}$ of each inoculant were used for the microtiter plate screening method using a 96 wells plate. Three different contaminants were used to identify new fungal species being able to grow in the presence of PCB $126\left(10 \mathrm{ng}^{\mathrm{l}} \mathrm{l}^{-1} \mathrm{PCP} 126\right.$ in isooctane, Dr. Ehrenstorfer GmbH), hexadecane (99\% analytical grade, Alfa Aesar) or toluene (Merck KGaA, Darmstadt, DE). Per contaminant $150 \mu \mathrm{l}$ of media, $50 \mu \mathrm{l}$ of contaminant solution and $20 \mu \mathrm{l}$ of the inoculum inoculant were used for hexadecane and PCB 126. Plates were kept at room temperature on a shaker. Toluene $(5 \%)$ was diluted with dibutyl phthalate in a beaker in a glass vacuum desiccator and plates were stored next to it to expose them to the volatile phase. Toluene plates were filled with $200 \mu \mathrm{l}$ of medium plus $20 \mu \mathrm{l}$ of inoculant. All tests were performed in triplicates, a negative control (medium without inoculant) was included on each plate. In addition, a positive control was carried out for each soil: $200 \mu \mathrm{l}$ of a glucose medium and $20 \mu \mathrm{l}$ of inoculant to investigate the number of fungal colonies deriving from the contaminated soil samples with glucose as carbon source. Growth of fungal species was measured through changes in the optical density (OD) at $700 \mathrm{~nm}$ with a microtiter plate reader Infinite M 1000 (Tecan, $\mathrm{CH}$, set at $24^{\circ} \mathrm{C}, 70.8 \mathrm{rpm}$, wavelength: $700 \mathrm{~nm}$, bandwidth: $5 \mathrm{~nm}$ ) and $\mathrm{OD}$ values were corrected with values of the negative control. After 10 days, fungal growth was observed in all wells, the screening method was stopped and the liquid of the microtiter plate wells was plated on 2\% malt extract agar (MEA: 2\% malt extract, $2 \%$ D-glucose, $0.1 \%$ bacto peptone, $2 \%$ agar) and RoseBengal Chloramphenicol agar (Merck) from the wells with the contaminant but also from the positive control to isolate fungal strains growing on glucose and PAHs. Fungal strains were isolated and pure cultures were cultivated.

\subsubsection{Screening of pure cultures for growth on contami- nant substrates toluene, hexadecane and PCB 126}

In order to test the ability of each isolated strain to live in the presence of the contaminants and to identify the best growing strains, the microtiter plate screening was repeated using pure cultures as inoculant rather than $\mathrm{PAH}$ contaminated soil. For this experiment, $1 \mathrm{~cm}^{2}$ of fungal biomass was diluted in $1 \mathrm{~mL}$ of $0.9 \%$ of sterile $\mathrm{NaCl}$ containing glass beads (Carl Roth, DE) and was homogenized on a Ribolyzer (FastPrep-24 Instrument, MP Biomedicals, CA) for $5 \mathrm{sec}$ at $4 \mathrm{~m} \mathrm{~s}^{-1}$. The screening protocol for PAH contaminated soils was also used to grow strains in triplicates at room temperature in the presence of hexadecane, PCB 126 or toluene. Additionally, positive and negative controls, as previously described, were set up and the plates were incubated for 27 days.

\subsection{DNA extraction and sequencing}

DNA extraction of the eleven best growing strains was done according to the protocol described in Sert and Sterflinger (Sert and Sterflinger, 2010). In this procedure, the fungal cells are disrupted through glass beads using a Ribolyzer for $20 \mathrm{sec}$ at $4 \mathrm{~m} \mathrm{~s}^{-1}$ twice, in-between samples 
were cooled on ice. DNA is recovered through Ethanol precipitation. The extracted DNA was tested on its purity on a Nanodrop 1000 spectrophotometer (Thermo Fisher) and bands were detected on an electrophoresis gel $1.5 \%$ $(\mathrm{w} / \mathrm{v})$. PCR of the ITS or $18 \mathrm{~S}$ rRNA sequences was done using the primer pair ITS1 / ITS4, further NL1 / NL4 and NS5 / NS8 at a concentration of $0.5 \mu \mathrm{M}$. For the PCR the protocol of the Phusion Polymerase (Thermo Fisher) was

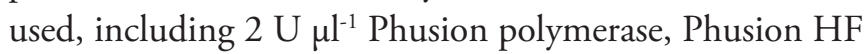
buffer (Thermo Fisher) and $10 \mathrm{mM}$ dNTPs. The Thermocycler (Biorad) was set up at $98^{\circ} \mathrm{C}(30 \mathrm{sec})$ for initial denaturation followed by 34 cycles at $98^{\circ} \mathrm{C} / 20 \mathrm{sec}, 60^{\circ} \mathrm{C} / 30$ sec and $72^{\circ} \mathrm{C} / 105 \mathrm{sec}$ and ended by the final elongation $72^{\circ} \mathrm{C} / 120 \mathrm{sec}$. After checking the obtained PCR products on an electrophoresis gel $1.5 \%(\mathrm{w} / \mathrm{v})$, the products were purified using the QIAquick PCR Purification Kit (Qiagen). Sequencing of the products was performed by Sanger Sequencing (Microsynth Austria). Sequencing results were compared with the online databases provided by the National Center for Biotechnology Information using the BLAST search program (Altschul et al., 1997) and sequences were deposited in the NCBI nucleotide database under the accession numbers listed in Table 1. Additionally, we did morphological and taxonomic analysis according to Domsch et al. (2008).

\section{Results and discussion}

\subsection{PAH measurements}

The total concentration of 16 US EPA PAH ranged from $20.53 \mathrm{mg} \mathrm{kg}^{-1}$ DW (soil sample (S) 10) to $867.77 \mathrm{mg}$ $\mathrm{kg}^{-1}$ DW (S 6). S $1-6$ contained a lower proportion of high molecular weight $\mathrm{PAHs}$ (HMW, $\geq 4$ aromatic rings, Figure 3) compared to $S 7-12$. According to literature (Lladó et al., 2013), samples with a high proportion of HMW PAHs are most likely aged contaminations due to the quicker dissipation of low molecular weight (LMW) PAHs in the field.

\subsection{Microtiter plate screening}

We were able to successfully adapt the microtiter plate screening method described by Blasi et al. (2016) to isolate 93 fungal colonies using the contaminated soil as inoculant. The soil contaminated with PAHs, acted as selective pressure for the microbiota to be able to isolate the fungal strains adapted to the contaminated environment. Two different microtiter plate screenings were performed:

- with soil as inoculant followed by isolation of fungal colonies (3.2.1)

- with pure strains after isolation and cultivation from the soil (3.2.2)

\subsubsection{Microtiter plate screening with soil inoculant}

As described above, soil samples varied in PAH content (Figure 3 and Table 2). This had a direct effect on the number of colonies isolated from the soil (Figure 1a, b). In the first plate screening, mixed cultures were obtained and resulted in 93 pure cultures. The highest amount of $\mathrm{PAH}$ was measured in S6. Nevertheless we could isolate two fungal colonies, one of them resulting in a successful candidate of the screening. In 6 out of 12 samples, a link between the proportion of HMW to total PAH concentration and the total number of isolated fungal communities was indicated by a strong linear regression (Figure 1a). The proportion of HMW / total PAH can be linked to the age of the contamination (Lladó et al., 2013). Accordingly, microorganisms in soil samples with lower proportion of HMW PAHs tend to be less adapted to contaminant degradation compared to microorganisms that could adapt to the contamination over a longer period of time in soil samples with a higher proportion of HMW PAHs. The 6 samples excluded from the regression analysis (S 7-12) were samples of very high HMW proportion, indicating high age. In these samples the microbial composition may have further changed because most degradable contaminants were already degraded. No correlation between individual PAHs and the ability to survive one of the three target contaminants could be found.

\subsubsection{Microtiter plate screening with pure cultures}

After the cultivation of pure cultures, the microtiter plate screening was repeated. Results are represented in Table 3. All values were corrected with the values of the negative controls.

For the 93 isolated fungal colonies, survival was highest in the presence of hexadecane (76\%) and toluene (56\%), likely due to a lower toxicity compared to the chlorinated PCB (LD50 Rat oral: Toluene 2.6 to $7.5 \mathrm{~g} / \mathrm{kg}$, PCB $4250 \mathrm{mg} / \mathrm{kg}$, Hexadecane not lethal; cf., U.S. National Library of Medicine). 20\% of the colonies showed slow or no growth in the pure strain screening, which can be explained by mutualism or by an additional carbon source 
such as dissolved organic carbon from the soil which was missing in the second screening using pure cultures.

Interactions and mutualism of different strains in the microbiota might play an important role for degradation as a study by Boonchan et al. (2000) showed.

After eliminating similar strains based on their macroscopic and microscopic appearance, we chose 11 fungal strains (Table 4) that showed a high increase in biomass (Absorbance $\geq 0.5$ for hexadecane or toluene, increasing absorbance with $\mathrm{PCB}$ ) and more than one microtiter plate setup (Figure 2a, $\mathrm{b}, \mathrm{c})$. These strains were chosen for identification through Sanger sequencing of the ITS or $18 \mathrm{~S}$ rDNA. We used different primer pairs to get the optimal coverage and identity using NCBI BLAST (Table 1). For most of the strains, growth in the presence of $\mathrm{PCB} 126$ was poorly visible. Only strains BL3 and U, identified as Ochroconis longiforum and Pyrenochaeta inflorescentiae, showed clear increase of OD values over 27 days. In the presence of hexadecane, all the strains but alpha 14 and BL4 showed high increase of OD values.
The two fungal strains only increased their biomass at the end of the test, and therefore, might need longer growth time. For 9 strains, an increase of OD in the presence of toluene was visible.

Nine out of 11 strains (as given in Table 1) have previously been reported as isolated from the contaminated sites. Especially good results in the microtiter plate screening showed Purpureocillium (Paecilomyces) lilacinum. The strain showed the greatest increase of biomass in the presence of hexadecane and toluene. It was reported to be isolated from various contaminated sites: plastics contaminated soil (Pradeep et al., 2013), from the acidic river Rio Tinto (Oggerin et al., 2013) and - classified as Penicillium lilacinum - from mine drainage containing high amounts of cadmium (Tatsuyama et al., 1975). The strain is very stress resistant, survives extreme conditions concerning $\mathrm{pH}$ values and heavy metal concentration but is also medically relevant as opportunistic pathogen (Luangsa-Ard et al., 2011).

Table 1. Phylogenetic classification of the ITS/18S rDNA coding sequences of the fungal isolates Tabelle 1. Phylogenetische Klassifikation der ITS/18S rDNA kodierenden Sequenzen der Pilzisolate

\begin{tabular}{|c|c|c|c|c|c|c|}
\hline No & Primer Pair & Closest identified phylogenetic relatives [EMBL accession numbers] & Query cover & Ident & ACBR strain No & accession No \\
\hline a 14 & NL1/NL4 & $\begin{array}{l}\text { Doratomyces purpureofuscus (Cephalotrichum purpureofuscum) } \\
\text { genomic DNA sequence contains } 28 \text { S rRNA gene, strain UAMH } \\
9209 \text { [LN851018.1] }\end{array}$ & $99 \%$ & $99 \%$ & MA6020 & KY454753 \\
\hline $\mathrm{O}$ & NS5/NS8 & $\begin{array}{l}\text { Roussoella intermedia strain CBS } 170.9618 \text { ribosomal RNA gene, } \\
\text { partial sequence [KF443390.1] }\end{array}$ & $99 \%$ & $100 \%$ & MA6025 & KY454758 \\
\hline Y & NL1/NL4 & $\begin{array}{l}\text { Purpureocillium sp. JCM } 28545 \text { gene for } 28 \text { S ribosomal RNA, partial } \\
\text { sequence [LC134235.1] }\end{array}$ & $100 \%$ & $99 \%$ & MA6015 & KY454754 \\
\hline BL 3 & NL1/NL4 & $\begin{array}{l}\text { Ochroconis longiphorum strain CBS } 435.7628 \mathrm{~S} \text { ribosomal RNA gene, } \\
\text { partial sequence [KF156135.1] }\end{array}$ & $96 \%$ & $99 \%$ & MA6021 & KY454755 \\
\hline BL 4 & NL1/NL4 & $\begin{array}{l}\text { Ochroconis longiphorum strain CBS } 435.7628 \mathrm{~S} \text { ribosomal RNA gene, } \\
\text { partial sequence [KF156135.1] }\end{array}$ & $99 \%$ & $99 \%$ & MA6017 & KY454756 \\
\hline V & ITS1/ITS4 & Penicillium janthinellum [EF634422.1] & $100 \%$ & $99 \%$ & MA6016 & KY454760 \\
\hline $\mathrm{Z}$ & ITS1/ITS4 & Pyrenochaeta inflorescentiae [EU552153.1] & $97 \%$ & $98 \%$ & MA6019 & KY454761 \\
\hline $\mathrm{H}$ & ITS1/ITS4 & Penicillium canescens [AY373901.1] & $100 \%$ & $99 \%$ & MA6018 & KY454762 \\
\hline \multirow[t]{2}{*}{$\mathrm{U}$} & NL1/NL4 & $\begin{array}{l}\text { Pyrenochaeta inflorescentiae culture-collection CBS: } 11922218 \mathrm{~S} \\
\text { ribosomal RNA gene, partial sequence; internal transcribed spacer } \\
1,5.8 \text { S ribosomal RNA gene, and internal transcribed spacer } 2 \text {, } \\
\text { complete sequence; and } 28 \mathrm{~S} \text { ribosomal RNA gene, partial sequence } \\
\text { [EU552153.1] }\end{array}$ & $99 \%$ & $99 \%$ & \multirow[t]{2}{*}{ MA6024 } & KY454757 \\
\hline & NS5/NS8 & $\begin{array}{l}\text { Pyrenochaeta sp. GMG_PPb7 18S ribosomal RNA gene, partial se- } \\
\text { quence; internal transcribed spacer 1, 5.8S ribosomal RNA gene, and } \\
\text { internal transcribed spacer } 2 \text {, complete sequence; and } 28 \mathrm{~S} \text { ribosomal } \\
\text { RNA gene, partial sequence [FJ439593.2] }\end{array}$ & $99 \%$ & $99 \%$ & & KY454759 \\
\hline $\mathrm{X} 1$ & ITS1/ITS4 & Purpureocillium lilacinum [KJ862077.1] & $99 \%$ & $100 \%$ & MA6022 & KY454763 \\
\hline G & ITS1/ITS4 & Penicillium canescens [AF033493.1] & $99 \%$ & $99 \%$ & MA6023 & KY454764 \\
\hline
\end{tabular}



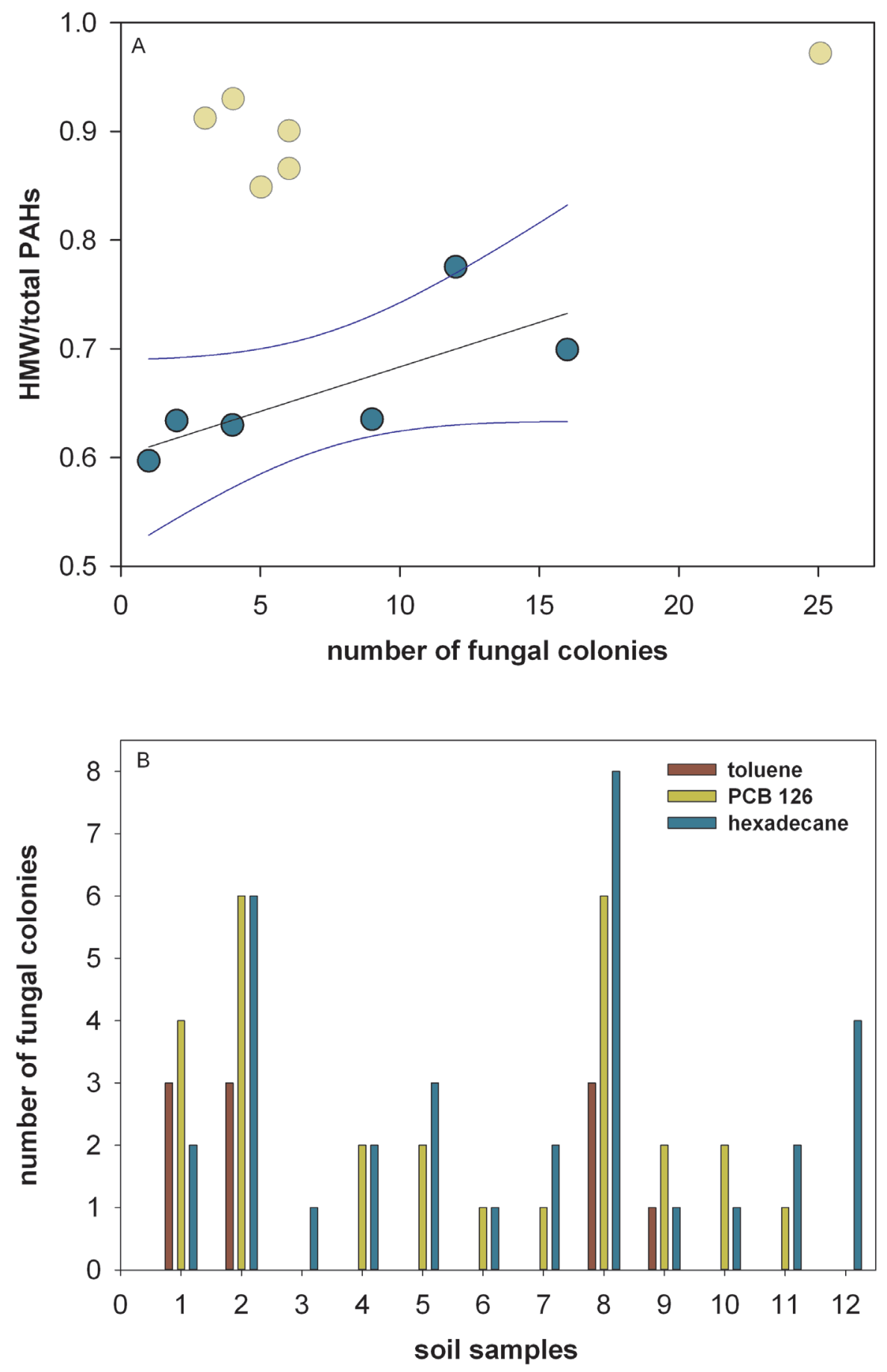

Figure 1. Regression model of PAH ratio against fungal colonies and fungal colonies isolated from each sample. A: Ratio of high molecular weight (HMW) PAHs to total PAHs on the $y$-axis against the total number of fungal colonies (x-axis) was plotted. A linear regression was done (black line) using the samples with low HMW/total PAH ratio (blue dots) with a confidence interval of $95 \%$ (blue line). The excluded samples with high HMW/total PAH ratio (indicating high age) was colored in green and excluded from the linear regression. B: Number of fungal colonies isolated from each sample grown on toluene (red), PCB 126 (green) and hexadecane (blue).

Abbildung 1. Regressionsmodell des PAK-Verhältnisses gegen die Anzahl der Pilzkolonien und der Gesamtanzahl der Pilzkolonien isoliert von den verschiedenen Proben. A: Verhältnis der hochmolekulargewichtigen (HMW) PAKs gegen die Gesamtanzahl der PAKs auf der y-Achse geplottet gegen die Gesamtanzahl der isolierten Pilzkolonien auf der x-Achse. Eine lineare Regressionsgerade wurde geplottet (schwarze Linie) mit Proben mit niedrigem HMW/total PAK Verhältnis (blau, runde Symbole) und ein Konfidenzintervall von 95 \% berechnet (blaue Linie). Proben mit hohem HMW/total PAK-Verhältnisses wurden nicht in die lineare Regression genommen (grüne Punkte). B: Anzahl der Pilzkolonien isoliert von jeder Probe, welche in Anwesenheit von Toluol (rot), PCB 126 (grün) und Hexadekan (blau) gewachsen sind. 

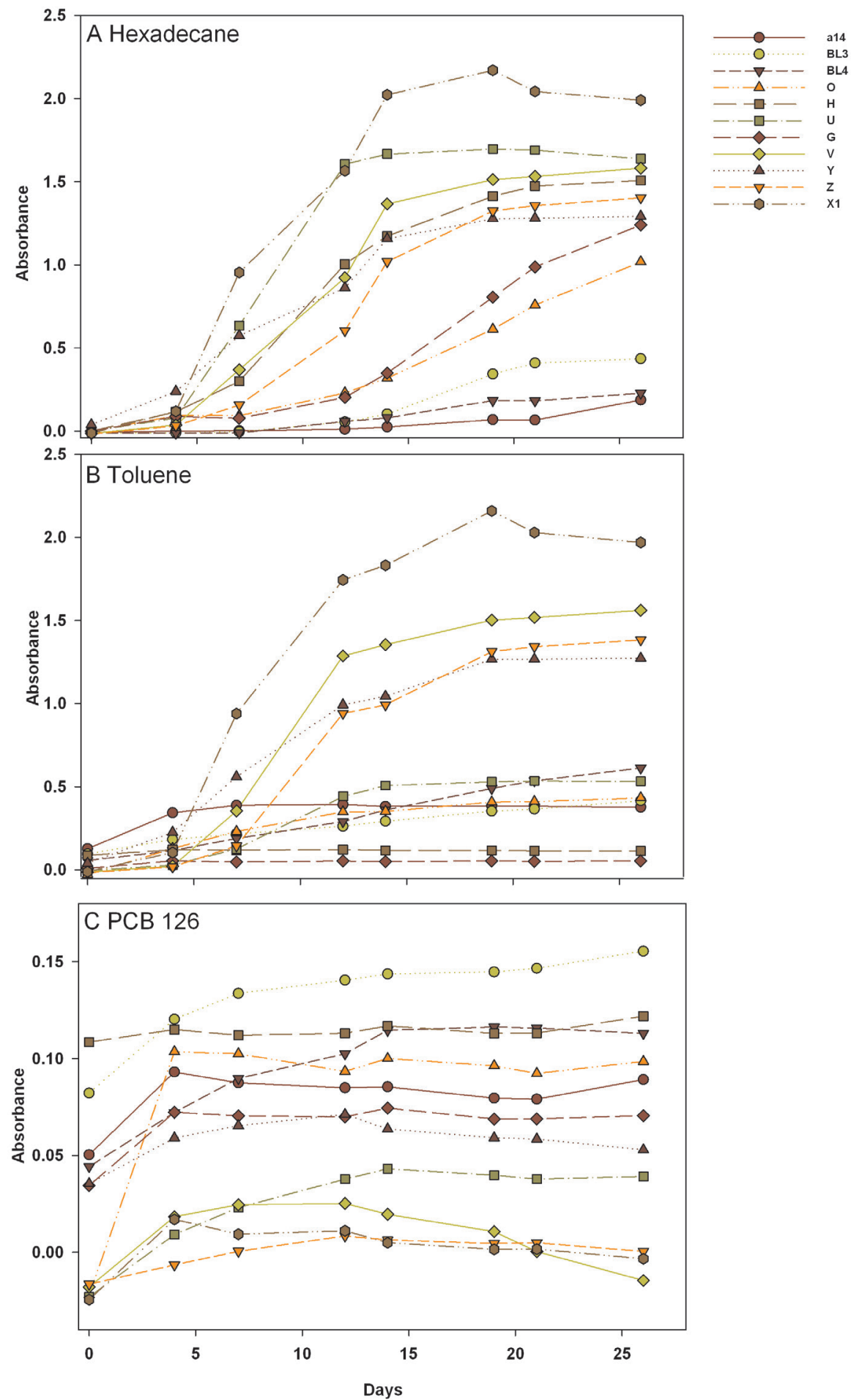

Figure 2. Fungal growth curves. Growth curves of the 11 selected fungal strains for identification grown in the presence of A hexadecane, B toluene and C PCB 126. Growth was measured through detected changes in the OD 700 using a Tecan reader.

Abbildung 2. Wachstumskurven der Pilzstämme. Wachstumskurven der 11 identifizierten Pilzstämme, die in Gegenwart von A Hexadekan, B Toluol und C PCB 126 gewachsen sind. Das Wachstum wurde durch Änderung der OD 700 mit Hilfe eines Tecan Readers detektiert. 
Table 2. GC Results: Measured US EPA PAH concentrations and standard deviations of the 12 soil samples (S1-12). Values are presented as mg/ $\mathrm{kg}$ dry weight and standard deviations were calculated $(\mathrm{mg} / \mathrm{kg}$ dryweight \pm standard deviation)

Tabelle 2. GC-Ergebnisse: Gemessene US EPA PAK-Konzentrationen und Standardabweichungen der 12 Bodenproben (S1-12) sind in der Tabelle dargestellt. Die Werte sind also $\mathrm{mg} / \mathrm{kg}$ Trockengeweicht dargestellt und die Standardabweichung wurde berechnet (mg/kg Trockengewicht \pm Standardabbweichung)

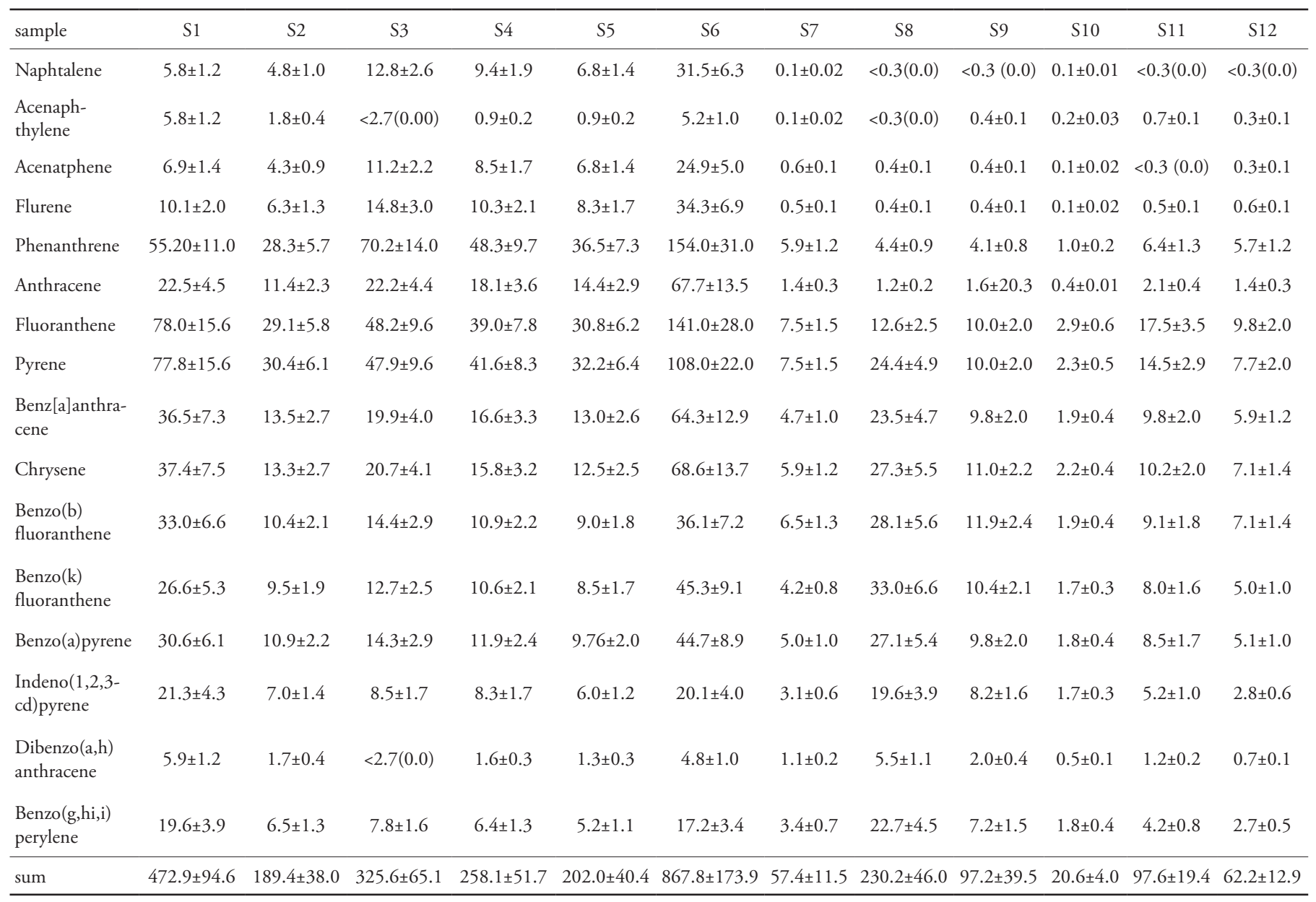

Ochroconis longiphorum (CBS 435.75) was isolated from the Canadian soil underneath the asphalt of a car park (Samerpitak et al., 2014), but also from the soil contaminated by a leaking diesel tank (Andreolli et al., 2016). Ochroconis longiphorum was formerly also described as Scolecobasidium longiphorum. In the genus Ochroconis, opportunistic infections of cold blooded vertebrates are reported but also for some thermophilic species warm-blood vertebrates might be a susceptible host (Samerpitak et al., 2014).

Pyrenochaeta inflorescentiae showed good growth in the presence of hexadecane and toluene. The reference listed in the Blast result (GenBank: EU552153.1) is deposited at the strain collection of the CBS-KNAW fungal biodiversity Center (CBS 119222), originating from Cape Town, from a senescent flowerhead. No degradation of contaminants of $P$. inflorescentiae was reported yet, but Pyrenochaeta sp. DS3sAY3a, was isolated from passive coal mine drainage treatment systems in central Pennsylvania, where toxic metals are removed from the drainage water (Santelli et al., 2010). Zeiner et al. (2016) concluded that Pyrenochaeta sp. could contribute to lignocellulose degradation by woodrot Basidiomycete fungi using cellulases and hemicellulases together with redox-active accessory enzymes in their cellulose-degrading capacity. This degrading capacity may be based on the direct enzymatic carbohydrate breakdown as well as indirect carbon oxidation via Fenton-based hydroxyl radical formation (Zeiner et al., 2016). Results from our study show that $P$. inflorescentiae can live in the presence of contaminants and might even be able to degrade them not only through co-metabolism with wood-rot fungi. 
Table 3. Results of the second microtiter plate screening: Number of colonies of having the same growth pattern of all 93 fungal isolates on toluene, hexadecane and PCB 126. + = good growth, - = very slow growth and - = no growth. Hex = hexadecane, Tol = toluene, $\mathrm{PCB}=\mathrm{PCB} 126$

Tabelle 3. Ergebnisse des zweiten Mikrotiterplatten-Screenings: Anzahl der Kolonien mit demselben Wachstumsmuster innerhalb der 93 isolierten Kolonien in Gegenwart von Toluol, Hexadekan und PCB 126. + = gutes Wachstum, - = sehr langsames Wachstum und - = kein Wachstum. Hex $=$ Hexadekan Tol $=$ Toluol, PCB $=$ PCB 126

\begin{tabular}{|c|c|c|c|}
\hline colony numbers & Hex & Tol & PCB \\
\hline 21 & + & + & - \\
\hline 14 & + & + & - \\
\hline 9 & + & + & + \\
\hline 8 & + & - & - \\
\hline 6 & + & - & - \\
\hline 5 & + & - & - \\
\hline 4 & - & - & - \\
\hline 3 & - & + & - \\
\hline 3 & + & - & - \\
\hline 2 & - & + & - \\
\hline 2 & $\sim$ & - & - \\
\hline 2 & - & - & - \\
\hline 2 & - & - & - \\
\hline 2 & $\sim$ & + & - \\
\hline 2 & + & - & + \\
\hline 2 & $\sim$ & - & + \\
\hline 1 & - & - & - \\
\hline 1 & - & - & - \\
\hline 1 & - & $\sim$ & - \\
\hline 1 & - & - & - \\
\hline 1 & - & - & + \\
\hline 1 & - & - & - \\
\hline
\end{tabular}

The isolation of Roussoella intermedia in this study pointed out as there is no report on the degradation of contaminants, but still the strain grew in the presence of all three contaminants. Roussoella intermedia was isolated from bamboo tree trunks in Papua New Guinea (CBS 170.96) and Hong Kong (ZHOU et al.) and it was isolated from north temperate lakes (Fallah-Moghaddam, 1999). Ligninolytic fungi as Roussoella are mostly wood degraders and they can be enriched through lignin-rich additions such as tree branches to soil (Bamforth and Singleton, 2005). Lignocellulosic material, which was colonized by the fungal strain originally, may have been added to the soil and the ligni-
Table 4. Growth pattern of the chosen fungal isolates for sequencing: $+=$ good growth, $-=$ very slow growth and $-=$ no growth. Hex = hexadecane, $\mathrm{Tol}=$ toluene, $\mathrm{PCB}=\mathrm{PCB} 126$

Tabelle 4. Wachstumsmuster der zum Sequenzieren ausgewählten Pilzisolate: + = gutes Wachstum, - = sehr langsames Wachstum und - = kein Wachstum. Hex $=$ Hexadekan Tol $=$ Toluol, PCB $=$ PCB 126

\begin{tabular}{lccc}
\hline No & Hex & Tol & PCB \\
\hline$\alpha 14$ & + & + & - \\
$\mathrm{O}$ & + & + & - \\
$\mathrm{U}$ & + & + & + \\
$\mathrm{V}$ & + & + & - \\
$\mathrm{X} 1$ & + & + & - \\
$\mathrm{Y}$ & + & + & - \\
$\mathrm{Z}$ & + & + & - \\
$\mathrm{BL} 3$ & + & + & - \\
$\mathrm{BL} 4$ & - & + & - \\
$\mathrm{G}$ & + & - & - \\
$\mathrm{H}$ & + & - & - \\
\hline
\end{tabular}

nolytic enzymes for wood degradation may have helped to degrade PAHs and the other contaminants tested.

Penicillium janthinellum shows significant growth in the presence of hexadecane, toluene and PCB 126, although the latter at a lower rate (Figure 2c). Penicillium janthinellum, renamed Penicillium simplicissimum was isolated from $S 1$ with the highest concentration of Pyrene, Chrysene and Benzo[a]pyrene. This is in line with literature where degradation of Pyrene, Chrysene, Benzo[a]pyrene (Cerniglia, 1997 ) by this strain is reported. Penicillium janthinellum has the ability to immobilize aluminum (Leitão, 2009) and was isolated from extremely acidic soil (Hujslová et al., 2017). Boonchan et al. (2000) suggest that P. janthinellum needs a bacterial co-culture to mineralize benzo[a]pyrene as a sole carbon and energy source. It is reported to degrade the aliphatic and aromatic fractions of crude oil (Oudot et al., 1987), oxidize chrysene (Kiehlmann et al., 1996) and April et al. (1999) report that $31 \%$ of the aliphatic fraction of Norman Well crude oil was degraded. Compared to other isolated fungal strains, it is not reported to be pathogenic for human and therefore, is a good candidate for bioremediation purposes.

Another good degrader for hexadecane might be Penicillium canescens. Penicillium canescens showed increased OD values in the presence of hexadecane and slightly with PCB. It was described by Say et al. (2003) as biosorbent for heavy metals from aqueous solutions and was therefore 


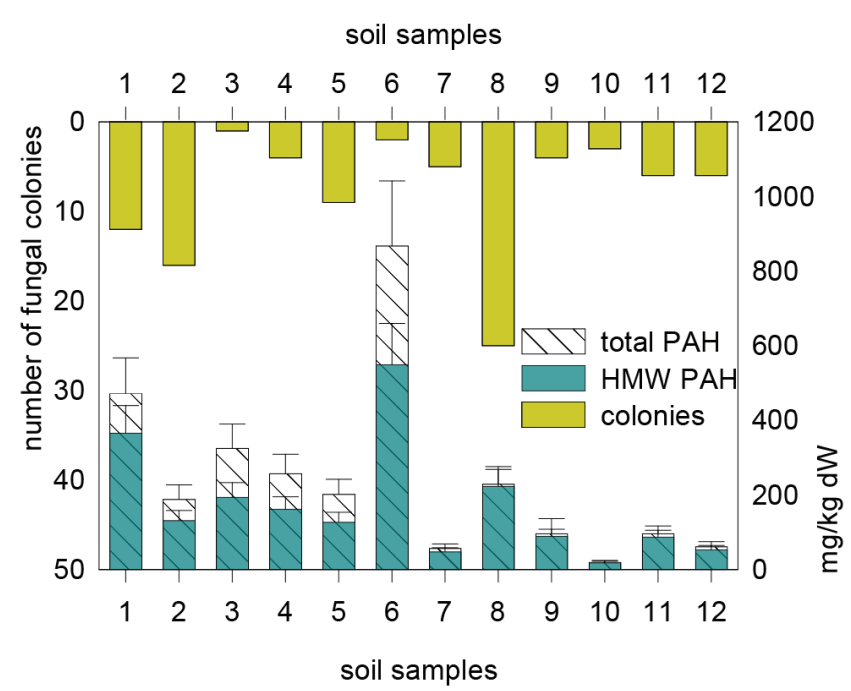

Figure 3. PAH concentrations and number of fungal colonies isolated from each sample. Top, left axis (green): Total sum of colonies isolated in the presence of toluene, PCB 126 or hexadecane, and wells containing glucose. Bottom, right axis: total concentration (pattern) and proportion of HMW PAHs (blue). X-axis presents the different samples.

Abbildung 3. PAK-Konzentrationen und die Anzahl der von jeder Probe isolierten Pilzkolonien. Obere, linke Achse: grün: Gesamtanzahl der Kolonien isoliert in Anwesenheit von Toluol, PCB 126 oder Hexadecan als einzige Kohlenstoffquelle und Näpfchen mit Glukose. Untere, rechte Achse: Gesamtkonzentration (Muster) und Proportion an hochmolekulargewichtigen PAKs (blau). Die x-Achse zeigt die verschiedenen Proben.

suggested as a strain for the cleanup of the environment, especially the aqueous systems. Further, it was shown to degrade dibenzofuran (Hammer et al., 2001). Garon et al. (2004) reported the isolation of the strain from a heavily $\mathrm{PAH}$ contaminated soil. Interestingly, it was isolated from S6, the sample with the highest amount of PAHs.

Doratomyces purpureofuscus was described by Bello Mouhamadou et al. (2013) as being isolated from the PCB contaminated soil and was shown to be able to degrade a mixture of 7 PCBs. It shows very slow growth with PCB 126 in this screening but increased growth in the presence of toluene. This non-pathogenic strain is successfully growing also in presence of hexadecane. Interestingly, 7 out of the 11 strains are opportunistic pathogens or have a close pathogenic strain within the genus. In the genus Roussoella, there is one reported opportunistic pathogen, RoussoeIla percutanea (Ahmed et al., 2014). In the genus Pyrenochaeta, the strain Pyrenochaeta romeroi (Yadav et al., 2015; Kulkarni et al., 2016) is reported to cause subcutaneous phaeohyphomycosis in transplant or diabetes patients (Ya- dav et al., 2015; Kulkarni et al., 2016). Purpureocillium (Paecilomyces) lilacinum is also reported as an opportunistic pathogen (Luangsa-Ard et al., 2011). This is in line with the hypothesis of Prenafeta et al. (2006), which suggests a linkage of microbial degradation potential and pathogenicity that might be due to the similarity of chemical structures of several brain components resembling alkylbenzene and lignin biodegradation intermediates.

\section{Conclusion}

In our study, we present the successful usage of a microtiter plate screening method for isolating the fungal strains from PAH contaminated soil. Microbiota originating from the contaminated soil is reported by Garon et al. (2004) to degrade contaminants better than the collection of originating reference strains. Our study combines the advantage of the quick, high throughput screening method and the selective pressure of contaminated soil. The method was proven successful not only of being able to isolate $93 \mathrm{cul}-$ tivable colonies but also 9 strains could be identified that are connected to the degradation of organic contaminants. The 11 identified strains could potentially be applied to bioremediation or biofilter systems. The strains are isolated from specific sites in Austria and should be well adapted for similar contaminated sites.

In 6 out of 12 samples, a link between the proportion of HMW to total PAH concentration and the total number of isolated fungal communities could be observed. Additionally, $20 \%$ of the strains were not able to grow the presence of the contaminants as a pure culture, which might be explained by mutualism with other fungal strains, other members of the soil microbiota, lack of substrate from the soil inoculant or difference in toxic pressure from the contaminant substrate.

The identified 11 strains can be used as a starting point for detailed research on carbon utilization and degradation performance. Especially, the use of the contaminants as sole carbon source without producing toxic cometabolites or additional carbon sources such as dibutyl phthalate from the microtiter plate material needs to be confirmed. Future work will have to address the toxicity of intermediate products, fate, degradation pathways, enzymes used and up and downregulated genes. While for ligninolytic fungi, a lot of studies concerning the enzymes involved in PAH degradation are available; for non-ligninolytic fungi, this information is lacking (Marco-Urrea et al., 2015). The correlation 
of 7 strains with the suggestion of Prenafeta et al. (2006), proposing a link between the capabilities of fungal strains to degrade contaminants and being neurotropic agents for warm-blooded vertebrates, has to be further investigated and might also help to understand fungal pathogenicity. Therefore it is of utmost importance to understand fungal degradation mechanisms and strains contributing to bioaugmentation to reduce the risk of spreading pathogenic microbes. More studies are needed to enable an effective usage of non-ligninolytic fungi, understand their degradation mechanisms, interaction with other microorganisms in degradation application and anticipate new effective technologies.

\section{Acknowledgments}

This project was financed by the Austrian Science Fund (FWF) (project number P 25119-B16).

\section{References}

Ahmed, S.A., Stevens, D.A., Van De Sande, W.W.J., Meis, J.F. and G.S. De Hoog (2014): Roussoella percutanea, a novel opportunistic pathogen causing subcutaneous mycoses. Medical Mycology 52, 689-698.

Altschul, S.F., Madden, T.L., Schäffer, A.A., Zhang, J., Zhang, Z., Miller, W. and D.J. Lipman (1997): Gapped BLAST and PSI-BLAST: a new generation of protein database search programs. Nucleic Acids Research 25, 3389-3402.

Andreolli, M., Albertarelli, N., Lampis, S., Brignoli, P., Khoei, N.S. and G. Vallini (2016): Bioremediation of diesel contamination at an underground storage tank site: a spatial analysis of the microbial community. World Journal of Microbiology and Biotechnology 32, 6 .

April, T.M., Foght, J.M. and R.S. Currah (1999): Hydrocarbon-degrading filamentous fungi isolated from flare pit soils in northern and western Canada. Canadian Journal of Microbiology 46, 38-49.

Atlas, R.M. (1995): Bioremediation of petroleum pollutants. International Biodeterioration \& Biodegradation 35, 317-327.

Bamforth, S.M. and I. Singleton (2005): Bioremediation of polycyclic aromatic hydrocarbons: current knowledge and future directions. Journal of Chemical Technology \& Biotechnology 80, 723-736.
Blasi, B., Poyntner, C., Rudavsky, T., Prenafeta-Boldú, F.X., Hoog, S. De, Tafer, H. and K. Sterflinger (2016): Pathogenic yet environmentally friendly? Black fungal candidates for bioremediation of pollutants. Geomicrobiology Journal 33, 308-317.

Boonchan, S., Britz, M.L. and G.A. Stanley (2000): Degradation and mineralization of high-molecular-weight polycyclic aromatic hydrocarbons by defined fungalbacterial cocultures. Applied and Environmental Microbiology 66, 1007-1019.

Cerniglia, C.E. (1997): Fungal metabolism of polycyclic aromatic hydrocarbons: past, present and future applications in bioremediation. Journal of Industrial Microbiology and Biotechnology 19, 324-333.

Cox, H.H.J. (1995): Styrene removal from waste gas by the fungus Exophiala jeanselmei in a biofilter. Thesis, Rijksuniversiteit Groningen, NL.

Domsch, K.H., Gams, W. and T.H. Anderson (1980): Compendium of soil fungi. Academic Press, London, UK.

Fallah-Moghaddam, P. (1999): Ascomycetes from north temperate lakes in Wisconsin. Thesis, University of Illinois at Urbana-Champaign, USA.

Garon, D., Sage, L. and F. Seigle-Murandi (2004): Effects of fungal bioaugmentation and cyclodextrin amendment on fluorene degradation in soil slurry. Biodegradation $15,1-8$.

Hammer, E., Schoefer, L., Schäfer, A., Hundt, K. and F. Schauer (2001): Formation of glucoside conjugates during biotransformation of dibenzofuran by Penicillium canescens. Applied Microbiology and Biotechnology 57, 390-394.

Harms, H., Schlosser, D. and L.Y. Wick (2011): Untapped potential: exploiting fungi in bioremediation of hazardous chemicals. Nature reviews. Microbiology 9, 177-192.

U.S. National Library of Medicine: Hazardous Substances Data Bank (HSDB). http://toxnet.nlm.nih.gov/cgi$\mathrm{bin} / \mathrm{sis} / \mathrm{htm}$ lgen?HSDB. Accessed on 8 January 2018.

Hujslová, M., Kubátová, A., Bukovská, P., Chudičková, M. and M. Kolař́k (2017): Extremely acidic soils are dominated by Species-poor and highly specific fungal communities. Microbial Ecology 73, 321-337.

Kiehlmann, E., Pinto, L. and M. Moore (1996): The biotransformation of chrysene to trans-1,2-dihydroxy-1,2dihydrochrysene by filamentous fungi. Canadian Journal of Microbiology 42, 604-608.

Kulkarni, M., Jamale, T., Hase, N., Ubale, M., Keskar, V. and P.K. Jagadish (2016): Subcutaneous Phaeohypho- 
mycosis caused by Pyrenochaeta Romeroi in a kidney transplant recipient: A Case Report. Experimental and Clinical Transplantation 14, E173-E174.

Kulshreshtha, S., Mathur, N. and P. Bhatnagar (2014): Mushroom as a product and their role in mycoremediation. AMB Express 4, 29.

Leitáo, A.L. (2009): Potential of Penicillium species in the bioremediation field. International Journal of Environmental Research and Public Health 6, 1393-1417.

Lladó, S., Covino, S., Solanas, A.M., Viñas, M., Petruccioli, M. and A. D'Annibale (2013): Comparative assessment of bioremediation approaches to highly recalcitrant PAH degradation in a real industrial polluted soil. Journal of Hazardous Materials 248, 407-414.

Luangsa-Ard, J., Houbraken, J., van Doorn, T., Hong, S.B., Borman, A.M., Hywel-Jones, N.L. and R.A. Samson (2011): Purpureocillium, a new genus for the medically important Paecilomyces lilacinus. FEMS Microbiology Letters 321, 141-149.

Maestre, J.P., Gamisans, X., Gabriel, D. and J. Lafuente (2007): Fungal biofilters for toluene biofiltration: Evaluation of the performance with four packing materials under different operating conditions. Chemosphere 67, 684-692.

Maqbool, Z., Hussain, S., Imran, M., Mahmood F., Shazad T., Ahmed Z., Azeem F. and S. Muzammil (2016): Perspectives of using fungi as bioresource for bioremediation of pesticides in the environment: a critical review. Environmental Science and Pollution Research 23, 16904-16925.

Marco-Urrea, E., García-Romera, I. and E. Aranda (2015): Potential of non-ligninolytic fungi in bioremediation of chlorinated and polycyclic aromatic hydrocarbons. New Biotechnology 32, 620-628.

Mollea, C., Bosco, F. and B. Ruggeri (2005): Fungal biodegradation of naphthalene: microcosms studies. Chemosphere 60, 636-643.

Mouhamadou, B., Faure, M., Sage, L., Marçais, J., Souard, F. and R.A. Geremia (2013): Potential of autochthonous fungal strains isolated from contaminated soils for degradation of polychlorinated biphenyls. Fungal Biology $117,268-274$.

Mrozik, A. and Z. Piotrowska-Seget (2010): Bioaugmentation as a strategy for cleaning up of soils contaminated with aromatic compounds. Microbiological Research 165, 363-375.

Oggerin, M., Tornos, F., Rodríguez, N., del Moral, C., Sánchez-Román, M. and R. Amils (2013): Specific jarosite biomineralization by Purpureocillium lilacinum, an acidophilic fungi isolated from Río Tinto. Environmental Microbiology 15, 2228-2237.

Oudot, J., Fusey, P., Abdelouahid, D.E., Haloui, S. and M.F. Roquebert (1987): Capacités dégradatives de bactéries et de champignons isolés d'un sol contaminé par un fuel. Canadian Journal of Microbiology 33, 232243.

Pinto, L.J. and M.M. Moore (2000): Release of polycyclic aromatic hydrocarbons from contaminated soils by surfactant and remediation of this effluent by Penicillium spp. Environmental Toxicology and Chemistry 19, 1741-1748.

Pradeep, S., Faseela, P., Josh, M.K.S., Balachandran, S., Devi, R.S. and S. Benjamin (2013): Fungal biodegradation of phthalate plasticizer in situ. Biodegradation 24, 257-267.

Prenafeta-Boldú, F.X., Summerbell, R. and G.S. de Hoog (2006): Fungi growing on aromatic hydrocarbons: biotechnology's unexpected encounter with biohazard? FEMS microbiology reviews 30, 109-130.

Said, O.B., Goñi-Urriza, M., El Bour, M., Aissa, P. and R. Duran (2010): Bacterial Community Structure of Sediments of the Bizerte Lagoon (Tunisia), a Southern Mediterranean Coastal Anthropized Lagoon. Microbial Ecology 59, 445-456.

Santelli, C.M., Pfister, D.H., Lazarus, D., Sun, L., Burgos, W.D. and C.M. Hansel (2010): Promotion of Mn(II) oxidation and remediation of coal mine drainage in passive treatment systems by diverse fungal and bacterial communities. Applied and Environmental Microbiology 76, 4871-4875.

Sasec, V. and T. Cajthaml (2014): Mycoremediation: current status and perspectives. International Journal of Medicinal Mushrooms 7, 360-361.

Say, R., Yilmaz, N. and A. Denizli (2003): Removal of Heavy Metal Ions Using the Fungus Penicillium canescens. Adsorption Science \& Technology 21, 643-650.

Sert, H.B. and K. Sterflinger (2010): A new Coniosporium species from historical marble monuments. Mycological Progress 9, 353-359.

Spigno, G., Pagella, C., Daria Fumi, M., Molteni, R. and D.M. de Faveri (2003): VOCs removal from waste gases: gas-phase bioreactor for the abatement of hexane by Aspergillus niger. Chemical Engineering Science 58, 739-746.

Tatsuyama, K., Egawa, H., Senmaru, H., Yamamoto, H., Ishioka, S., Tamatsukuri, T. and K. Saito (1975): Peni- 
cillium lilacinum: Its tolerance to cadmium. Experientia 31, 1037-1038.

van Groenestijn, J.W., van Heininge, W.N. and N.J. Kraakm (2001): Biofilters based on the action of fungi. Water Science \& Technology 44, 227-232.

van Groenestijn, J.W. and N.J.R. Kraakman (2005): Recent developments in biological waste gas purification in Europe. Chemical Engineering Journal 113, 85-91.

Yadav, S., Agarwal, R., Singh, S. and S. Goel (2015): Pyrenochaeta romeroi causing subcutaneous phaeohyphomycotic cyst in a diabetic female. Medical Mycology Case Report 8, 47-49.

Zeiner, C.A., Purvine, S.O., Zink, E.M., Paša-Tolić, L., Chaput, D.L., Haridas, S., Wu, S., LaButti, K., Grigoriev, I.V., Henrissat, B., Santelli, C.M. and C.M. Han- sel (2016): Comparative Analysis of Secretome Profiles of Manganese(II)-Oxidizing Ascomycete Fungi. PLOS ONE 11, e0157844.

Zhou, D., Cai, L. and K.D. Hyde (2003): Astrosphaeriella and Roussoëlla species on bamboo from Hong Kong and Yunnan, China, including a new species of Roussoëlla. Cryptogamie. Mycologie 24, 191-197.

\section{Acknowledgment}

The authors would like to thank Gabriel Sigmund from the University of Vienna for fruitful discussions and scientific input. 